Історико-політичні проблеми сучасного світу: Збірник наукових статей. - Чернівці: Чернівецький національний університет, 2019. - T. 40. - C. 101-109

DOI: $10.31861 / \mathrm{mhpi} 2019.40 .101-109$

УДК: 322.146:330.322](438.17)
Modern Historical and Political Issues: Journal in Historical \& Political Sciences. - Chernivtsi: Chernivtsi National University, 2019. - Volume. 40. - pp. 101-109 DOI: $10.31861 / \mathrm{mhpi2019.40.101-109}$

\title{
The assessment of the Effectiveness of the Implementation of Infrastructural Investments within the Regional Operational Programme for the Podkarpackie Province Throughout 2007-2013
}

This article aims to assess the effects of the implementation of infrastructural investments within the Regional Operational Programme for the Podkarpackie Province for the years 2007-2013. The article was prepared based on the examination method of documents that included the Regional Operational Programme for the Podkarpackie Province for the years 2007-2013, the Annual Report (for 2014) and Periodical Report (for the second half of 2015) on the implementation of the Programme, Monitor Regionalny, The report - the situation at the end of July 2015. The conducted analysis shows that most assumed material project indicators, i.e. output and result indicators, were achieved. As a result of the implementation of the Programme $924 \mathrm{~km}$ of regional roads were modernized, $76 \mathrm{~km}$ of regional roads were built, 107 units of municipal transport fleet were purchased and modernized, a 58 $\mathrm{km}$ broadband network was built, 13406 entities have gained access to the broadband Internet, 157 units of fire engines were purchased within the projects in the field of the protection against forest fires and other threats, 190369 persons were connected to the water supply network, 78343 persons were connected to the sewage system, 59 educational facilities were modernized, 20 lifelong learning schools were supported, 26 health care centres were modernized, 19 social welfare institutions were modernized, and 40 sports and leisure facilities were built. It is worth noting that by the end of July 2015 , projects using all available allocation of funds were contracted and the beneficiaries of the Programme were paid more than $94 \%$ of the funds within the available allocation, which puts the Podkarpackie Province on the third place on the background of the country.

Keywords: EU funds, European funds, structural funds, regional programmes, the European Regional Development Fund, Podkarpackie Province.

\section{Оцінка ефективності реалізації інвестицій в інфраструктуру в рамках Регіональної операційної програми Підкарпатського воєводства на 2007-2013 роки}

Метою статті є оцінка наслідків реалізації інвестицій в інфраструктуру Підкарпатського воєводства, які здійснювалися у рамках Регіональної операційної програми на 2007-2013 роки. Стаття була приготована на основі методу вивчення документів, зокрема таких як: Регіональна операційна програма Підкарпатського воєводства на 2007-2013 роки, річний звіт (за 2014 р.) та періодичний звіт (за II півріччя 2015 р.) про виконання Програми, Регіональний моніторинг, Рапорт - станом на кінець липня 2015 р. Як показує проведений аналіз, досягнуто більшість закладених істотних показників реалізації проекту, тобто показники продукту та результату. Як наслідок виконання Програми, зокрема модернізовано 924 км регіональних доріг, побудовано 76 км доріг регіонального значення, придбано та модернізовано 107 одиниць техніки для автопарку міського транспорту, побудовано 58 км широкосмугової мережі Інтернет, 13406 суб'єктів отримали доступ до широкосмугової мережі Інтернет, в рамках проектів протипожежних заходів в лісових масивах та інших загроз придбано 157 одиниць пожежного транспорту, до водопровідної мережі під'єднано 190399 осіб, до каналізаційної мережі під'єднано 78343 особи, модернізовано 59 освітніх об'єктів, надано підтримку 20 закладам безперервної освіти, модернізовано 26 закладів охорони здоров'я, модернізовано 19 закладів соціального захисту

\footnotetext{
${ }^{1}$ Dr Wojciech Lichota, Department of Finances, Faculty of Economics, University of Rzeszów, The Republic of Poland. E-mail: wlichota@tlen.pl.
} 
населення, побудовано 40 спортивно-оздоровчих закладів. Варто зазначити, що до кінця липня 2015 р. було укладено договори щодо проектів на всю доступну виділену суму коштів та було виділено бенефіціарам Програми понад 94\% коштів в рамках доступних асигнувань, що надає Підкарпатському воєводству третє місце в масштабах держави.

Ключові слова: фонди Європейського Союзу, Європейські фонди, структурні фонди, регіональні програми, Свропейський фонд регіонального розвитку, Підкарпатське воєводство.

\section{Ocena efektywności wdrażnia inwestycji infrastrukturalnych w ramach Regionalnego Programu Operacyjnego Województwa Podkarpackiego na lata 2007 - 2013}

Celem artykułu jest ocena efektów wdrażania inwestycji infrastrukturalnych w ramach Regionalnego Programu Operacyjnego Województwa Podkarpackiego na lata 2007-2013. Artykuł został przygotowany w oparciu o metodę badania dokumentów jakimi były w szczególności: Regionalny Program Operacyjny Województwa Podkarpackiego na lata 2007-2013, Sprawozdanie roczne (za 2014 r.) i okresowe (za II półrocze 2015 r.) z realizacji Programu, Monitor Regionalny, Raport - stan na koniec lipca 2015 r. Jak wynika z dokonanej analizy większość założonych rzeczowych wskaźników realizacji projektu, tj. wskaźników produktu i rezultatu zostało osiągniętych. W wyniku realizacji Programu, m.in. zmodernizowano $924 \mathrm{~km}$ dróg regionalnych, wybudowano 76 km dróg regionalnych, zakupiono i zmodernizowanego 107 szt. taboru komunikacji miejskiej, wybudowano $58 \mathrm{~km}$ sieci Internetu szerokopasmowego, dostęp do szerokopasmowego Internetu uzyskało 13406 podmiotów, zakupiono 157 szt. wozów pożarniczych w ramach projektów w zakresie zabezpieczenia przed pożarami lasów i innymi zagrożeniami, przyłączono do sieci wodociągowej 190 369 osób, przyłączono do sieci kanalizacyjnej 78343 osoby, zmodernizowano 59 obiektów edukacyjnych, wsparto 20 placówek prowadzących działalność w zakresie kształcenia ustawicznego, zmodernizowano 26 zakładów opieki zdrowotnej, zmodernizowano 19 obiektów pomocy społecznej, wybudowano 40 obiektów sportowych lub rekreacyjnych. Warto podkreślić, że do końca lipca $2015 \mathrm{r}$. zakontraktowano projekty na całą dostępną alokację środków i wydatkowano na rzecz beneficjentów Programu ponad $94 \%$ środków w ramach dostępnej alokacji, co stawia województwo podkarpackie na trzecim miejscu na tle kraju.

Słowa kluczowe: fundusze unijne, fundusze europejskie, fundusze strukturalne, programy regionalne, Europejski Fundusz Rozwoju Regionalnego, województwo podkarpackie.

\section{Introduction.}

The Regional Operational Programme for the Podkarpackie Province for the years 2007-2013 (ROP WP programme) is the most important instrument of the regional development policy for the period 2007-2015 $5^{2}$. The overall objective of ROP WP programme is the growth of domestic and international competitiveness of the economy and the improvement of the spatial accessibility of the Podkarpackie Province ${ }^{3}$. This goal is achieved through structural investments aimed at, among others, enhancing the accessibility of the region, increasing its competitiveness, promoting innovation, improving the natural and cultural environment, and raising the level of education. The specific objectives of ROP WP programme ${ }^{4}$ were determined based on an analysis of the level of socio-economic development of the province and cover the most important areas of intervention that require support in order to remove the main barriers to development and raise the level of economic development of the province 5 .

\footnotetext{
2 As part of the Regional Operational Programme for the Podkarpackie Province for the years 2007-2013, the expenses incurred by the end of 2015 may be considered as an eligible cost of the projects.

3 J. Sierak, A. Karasek, O. Korniienko, A. Godlewska, A. Łubian, M. Sienicki, A. Boczkowska, A. Kucyk, Efekty wykorzystania dotacji unijnych w ramach Regionalnych Programów Operacyjnych w latach 2007-2013, Cz. 2, Województwa Polski Wschodniej i Centralnej, Oficyna Wydawnicza Uczelni Łazarskiego, Warszawa 2016, p. 49.

${ }^{4}$ The Regional Operational Programme for the Podkarpackie Province for the years 2007-2013 adopted by the Board of Podkarpackie Province on 10 January 2012, p. 4.

5 W. Karpińska-Mizielińska, T. Smuga (red.), 2015, Wpływ interwencji z funduszy unijnych, CeDeWu, Warszawa, p.157.
} 
The Regional Operational Programme for the Podkarpackie Province for the years 2007-2013 set eight priority axes.

The overriding objective set for axis I.: Competitive and Innovative Economy is to create conditions for the development of entrepreneurship and economy based on knowledge. The achievement of this objective will be carried out through the following specific objectives:

- the support for the development of the existing enterprises and the creation of new ones,

- the increase in the availability of external sources of financing,

- the development of a network of business environment institutions,

- the creation of the conditions for economic development and growth of the innovation potential in the region and the transfer of knowledge,

- the increase in the investment attractiveness and the support of activities in the field of interregional and international cooperation.

Implementation of axis II. Technical Infrastructure will improve the accessibility and investment attractiveness of the region through the implementation of projects in the sphere of transport and energy.

The specific objectives identified under axis II. include:

- the improvement of transport links and public transport system in the province,

- the improvement of the condition and efficient use of energy infrastructure.

The creation of the conditions for development of information society in the region is realized under axis III: Information Society. The improvement of the quality of information infrastructure will allow closing significantly the gap between the region and the more developed regions of the country and the European Union.

The prevention of environmental degradation and natural and technological hazards, as well as the effective management of natural resources are the overriding objective of axis IV. Environmental Protection and Risk Prevention.

The implementation of this objective will contribute:

- water supply,

- to improve flood protection and to manage water resources in a rational manner,

- to reduce the degradation of the environment and to conserve the biological diversity,

- to improve the level of security in the region in terms of natural and technological hazards.

The objective of axis V.: Public Infrastructure is to create the conditions for the development of social capital through investments in education, health care, social welfare, sports and recreation.

The specific objectives identified under this axis include:

- the improvement of the accessibility and quality of the regional education system,

- the improvement of health security and the development of social welfare infrastructure,

- the increase in the availability of residents to sports and recreational facilities.

The increase in the share of tourism in the regional economy and the protection of cultural heritage and the development of cultural institutions will be ensured by the implementation of axis VI. Tourism and Culture. Particularly so, since the province has a significant but unused potential both in the area of tourism and culture.

The reduction of disparities in development within the region by strengthening urban centres, the socio-economic recovery of degraded areas and the increase in the investment attractiveness of economically marginalized areas will be carried out through the implementation of activities planned under axis VII. Intra-Regional Cohesion.

Implementation of axis VIII. Technical Assistance, is aimed at the effective implementation of ROP WP programme, including:

- enabling the efficient functioning of the programme implementation system and ensuring the continuity of programming,

- disseminating information about available support within the Regional Operational Programme for the Podkarpackie Province and promoting the effects of the programme,

- ensuring the correct preparation of projects in order to improve their implementation,

- full participation in a uniform computerized monitoring system ${ }^{6}$.

\footnotetext{
${ }^{6}$ A detailed description of the priorities of the Regional Operational Programme for the Podkarpackie Province for the years $2007-2013$ of 15 April 2014, pp. 4-5.
} 
This article will assess the implementation of the Regional Operational Programme for the Podkarpackie Province for the years 2007-2013 in terms of the infrastructure, i.e. under axes II-VII.

Since the first calls for projects were announced in 2008 and the contracting of projects started in 2008 , the majority of the projects that received funding have already been completed and settled. It should be noted that the Regional Operational Programme for the Podkarpackie Province for the years 2007-2013 has now entered its final phase of implementation because the calls for applications are no longer expected to be carried out ${ }^{7}$, almost the entire allocation of the funds available under the ROP WP programme was contracted ${ }^{8}$, and the final date of the expenditure eligibility is 31 December $2015^{9}$.

Chart 1 presents the amounts allocated to the implementation of individual ROP WP programme axes.

The system of priority axes of ROP WP programme (ERDF allocation in millions EUR)

Chart 1.

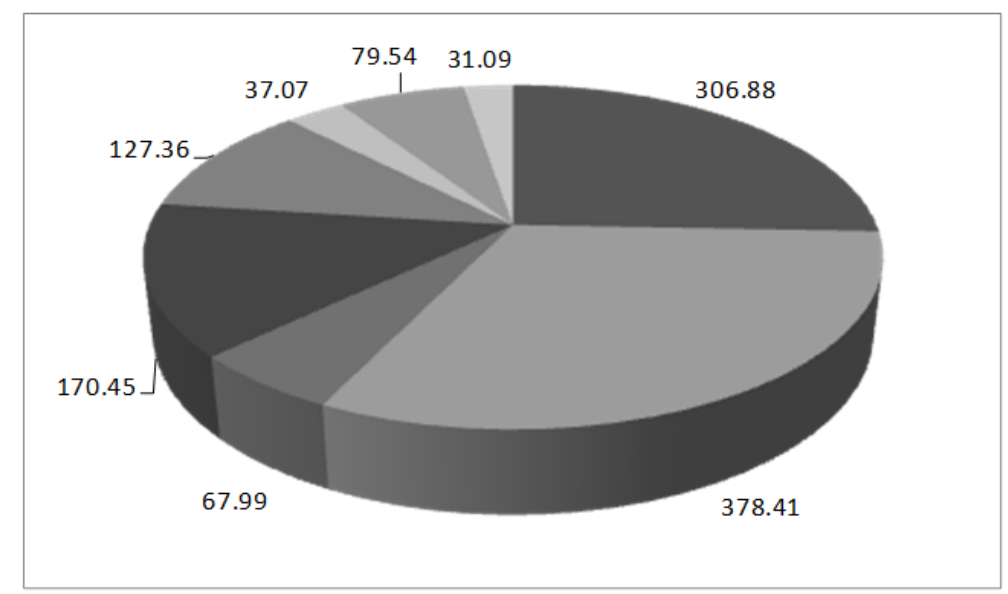

Source: Periodical Report on the implementation of the Regional Operational Programme for the Podkarpackie Province for the years 2007-2013 for the second half of 2015.

Axis I - Competitive and Innovative Economy - 306.88 millions EUR, Axis II - Technical Infrastructure - 378.41 millions EUR, Axis III - Information Society - 67.99 millions EUR, Axis IV - Environmental Protection and Risk Prevention - 170.45 millions EUR, Axis V - Public Infrastructure 127.36 millions EUR, Axis VI - Tourism and Culture - 37.07 millions EUR, Axis VII - IntraRegional Cohesion - 79.54 millions EUR, Axis VIII - Technical Assistance - 31.09 millions EUR.

2. Financial and material effects of the implementation of the individual axes II to VII of the Regional Operational Programme for the Podkarpackie Province ${ }^{10}$.

The material effects of the implementation of the Programme are measured by product indicators that relate to the direct effects of the implementation of the project (e.g. $2 \mathrm{~km}$ of a road, 3 buildings) and outcome indicators that characterize the impact of the completed project on the environment, obtained immediately after its completion (e.g. shortening of the travel time from village A to village B in connection with the modernization of a road, or the amount of energy savings as a result of the thermal modernization of a building).

The effects presented in the article will therefore have a direct reference in the form of indicators achieved.

\footnotetext{
7 Annex to Resolution No. 328/7836/14 of the Board of the Podkarpackie Province in Rzeszów of 11 March 2014.

${ }^{8}$ Annual Report on the implementation of the Regional Operational Programme for the Podkarpackie Province for the years 2007-2013 for 2014, p. 6 and the Use of EU funds under the National Cohesion Strategy 20072013, Warsaw, July 2015.

${ }^{9}$ [Manual of expenditure eligibility under the Regional Operational Programme for the Podkarpackie Province for the years 2007-2013, September 2014, p. 11

${ }^{10}$ Based on the Periodical Report on the implementation of the Regional Operational Programme for the Podkarpackie Province for 2007-2013 for the second half of 2015.
} 
Under axis II. Technical Infrastructure, since the launch of the Programme, 462 projects (including 27 key projects) were contracted for the amount of $1622798975.81 \mathrm{zl}$ of the ERDF, which represents $100 \%$ of the allocation of axis II.: Technical Infrastructure. The amount of $1516485067.56 \mathrm{zt}$ of the ERDF was approved and disbursed, which represents $93 \%$ of the allocation of axis II.

Under the above mentioned priority axis:

- over $76 \mathrm{~km}$ of new roads were built $(67.2 \mathrm{~km}$ of municipal and district roads and $9.5 \mathrm{~km}$ of provincial roads)

$-924 \mathrm{~km}$ of roads were modernized (882.5 $\mathrm{km}$ of municipal and district roads and $41.5 \mathrm{~km}$ of provincial roads)

$-23.6 \mathrm{~km}$ of roads damaged by flooding were reconstructed,

$-75 \mathrm{~km}$ of railway lines were reconstructed,

- 107 units of municipal transport fleet were purchased and modernized ${ }^{11}$,

- additional power of renewable energy was installed, which amounted to $23.6 \mathrm{MW}$,

-5 units of rolling stock were purchased.

However, the following indicators will not be achieved, e.g.

- The number of passenger kilometres in the purchased / modernized public transport fleet $(0.86 \%)$,

- The length of new railway lines $(0 \%)$,

- The amount of purchased rolling stock (45\%),

- The length of new regional (provincial) roads $(47 \%)$,

- The length of reconstructed regional (provincial) roads $(41 \%)^{12}$,

because they were overestimated at the stage of the Programme creation, projects that allow achieving these indicators were not submitted for funding or a diagnosis was confirmed that there is a good road network in the Podkarpackie Province, so there is no need to build new roads but the existing ones must be modernized.

Under axis III: Information Society, 60 agreements / decisions (including contracting 24 key projects) were signed for $280607522.7 \mathrm{zl}$ of the ERDF, which represents $100 \%$ of the allocation amount of axis III. The amount of $237876181.25 \mathrm{zl}$ of the ERDF was approved and disbursed, which represents $84 \%$ of the allocation of axis III.

Under the above mentioned priority axis:

$-58.7 \mathrm{~km}$ of the broadband internet network were built,

-360 public services were delivered on-line,

- 52077 persons gained access to the broadband internet, including 38577 persons in rural areas,

- 13406 entities (households - 12 300, SMEs - 1095, schools - 10, public administration entities - 1) gained access to the broadband internet,

- The number of users of on-line services amounted to 9392452 persons.

- However, the following indicators will not be achieved, e.g.

- The number of entities that gained access to the broadband internet, including schools (37\%),

- The number of entities that gained access to the broadband internet, including public administration entities $(8 \%)^{13}$,

because the projects that allow for the completion of specified indicators were not submitted.

Under axis IV. Environmental Protection and Risk Prevention, 256 projects (including 4 key projects) were contracted for the amount of $692449815.14 \mathrm{zl}$ of the ERDF, which represents $100 \%$ of the allocation amount of axis IV. The amount of $664355135.25 \mathrm{zl}$ of the ERDF was approved and disbursed, which represents $96 \%$ of the allocation of axis IV.

Under the above mentioned priority axis:

$-669 \mathrm{~km}$ of water networks were built, including $584 \mathrm{~km}$ in rural areas,

$-1547 \mathrm{~km}$ of sewerage networks were built, including $1518 \mathrm{~km}$ in rural areas,

-157 units of fire engines were purchased within the projects in the field of protection against forest fires and other hazards,

${ }^{11}$ W. Lichota, Wykorzystanie funduszy UE w ramach perspektywy 2007-2013 a możliwości pozyskania środków w ramach perspektywy 2014-2020 na przykładzie wybranej gminy z województwa podkarpackiego, Nierówności Społeczne a Wzrost Gospodarczy, nr 49 (1/2017), s. 254.

${ }^{12}$ The percentage level of achievement of the target value for 2015 according to the signed contracts is given in brackets.

${ }^{13}$ W. Lichota, Op. cit. 
- 190369 persons were connected to the water supply network,

-78343 persons were connected to the sewage system,

- selective waste collection system was made for 134344 persons,

- 43282 persons were protected against flooding,

-1791 companies were protected against flooding,

- 17564 ha of the area were protected against flooding,

- 326654 persons were covered by projects involving waste management,

$-25 \mathrm{~km}$ of flood embankments were built / modernized,

- 92 pieces of buildings / flood control facilities other than embankments and drainage buildings / facilities were built / modernized,

$-46 \mathrm{~km}$ of watercourses were subjected to regulations or other drainage works,

-20 endangered species were covered by protective measures,

-9500 ha of habitats were covered by monitoring,

-35 million zł was the value of the property protected against the risk of landslides.

The following indicators will not be achieved, e.g.:

- The number of projects in the field of waste management (41\%),

- The area of reclaimed land because of the projects (57\%),

- The number of residents served within projects related to waste management (38\%),

- The length of built / modernized flood embankments (65\%),

- The number of people protected from flooding because of the projects (43\%),

- The number of projects related to natural inventory, development of conservation plans for NATURA 2000 sites, landscape parks and nature reserves (60\%),

- The number of projects in the field of the conservation of natural habitats, species of plants, animals and fungi (50\%),

- The number of projects involving the construction of wildlife crossings and / or the elimination of environmental barriers $(0 \%)$,

- The size of the area covered by the impact of the projects $(4.58 \%)^{14}$.

The failure to reach the specified indicators is associated with considerable difficulties in preparing and implementing of this scope projects and with less efficiency of the projects in relation to the assumptions. The lack of projects on wildlife crossings may be because of the fact that specific areas that need this type of action have not yet been identified in the Podkarpackie Province.

Under axis V.: Public Infrastructure, 221 agreements / decisions (including 16 key projects) were signed for $529618849.82 \mathrm{zl}$ of the ERDF, which represents $100 \%$ of the allocation available under axis V: Public Infrastructure. Applications for payment were approved, under which beneficiaries were paid the amount of $509702714.98 \mathrm{zl}$ of the ERDF, which represents $96 \%$ of the allocation of axis V.

Under the above mentioned priority axis:

-59 educational facilities were modernized,

-20 lifelong learning schools were supported,

-37318 pupils and 21443 students benefited from the effects of the projects,

-2316 children attend the built or modernized rural kindergartens,

- 352982 patients per year benefit from the effects of the projects involving healthcare,

-470230 specialised medical examinations were conducted using the equipment purchased as a result of the projects,

-29125 persons benefit from the effects of the projects involving social assistance,

-26 health care facilities were modernized,

- 19 social assistance facilities were modernized,

-40 sports and leisure facilities were built,

-19 sports and leisure facilities were equipped,

-7 sports and leisure facilities damaged by the flood were rebuilt / renovated.

The indicator "The number of modernized social assistance facilities" will not be achieved $(51 \%)^{15}$, because an insufficient number of projects which include the modernization of social assistance facilities was submitted.

\footnotetext{
${ }^{14}$ W. Lichota, Op. cit.
} 
Under axis VI. Tourism and Culture, 72 agreements / decisions (including contracting 3 key projects) were signed, for a total amount of $148572727.64 \mathrm{zł}$ of the ERDF, which represents $100 \%$ of the allocation of axis VI: Tourism and Culture. Applications for payment were approved, under which beneficiaries were paid the amount of $144616057.35 \mathrm{zl}$ of the ERDF, which represents $97 \%$ of the allocation of axis VI.

Under the above mentioned priority axis:

-81 cultural institutions were supported,

-53 workplaces in tourism were created,

-76 cultural heritage sites were opened to tourism.

Under axis VII. Intra-Regional Cohesion, 143 contracts (including contracting 1 key project) were signed for the amount of $323798383.55 \mathrm{zl}$ of the ERDF, which represents $100 \%$ of the allocation of axis VII: Intra-Regional Cohesion. Applications for payment were approved, under which beneficiaries were paid the amount of $310915049.39 \mathrm{zl}$ of the ERDF, which represents $96 \%$ of the allocation of axis VII.

Under the above mentioned priority axis:

-630469 sq. m of buildings were renovated,

-14 companies were founded in the renovated areas,

-74 workplaces were created in the renovated areas,

- the infrastructure damaged by the flood, worth 54.9 million zł, was reconstructed.

The following indicators will not be achieved, e.g.

- The number of companies established in the renovated areas (activity $7.2-14 \%$ ),

- The number of workplaces created in the renovated areas (activity $7.2-58 \%$ ),

- The number of projects promoting entrepreneurship and the use of new technologies (activity 7.3 $17 \%)$,

- The number of companies established in the renovated areas (activity $7.3-0 \%)^{16}$,

Most likely, these indicators were overestimated at the stage of the Programme creation.

3. The status of implementation of the Regional Operational Programme for the Podkarpackie Province for the years 2007-2013 against the background of the country.

By the end of July 2015, within 16 regional programmes 36.2 thousand agreements on funding were signed for the amount of 110.9 billion zł, including EU funding - 71.3 billion zł. (see chart 2).

\section{Contracting of individual ROP programmes - the value of the contracts (EU funds, million zl) and the use of the allocation (\%).}

Chart 2.

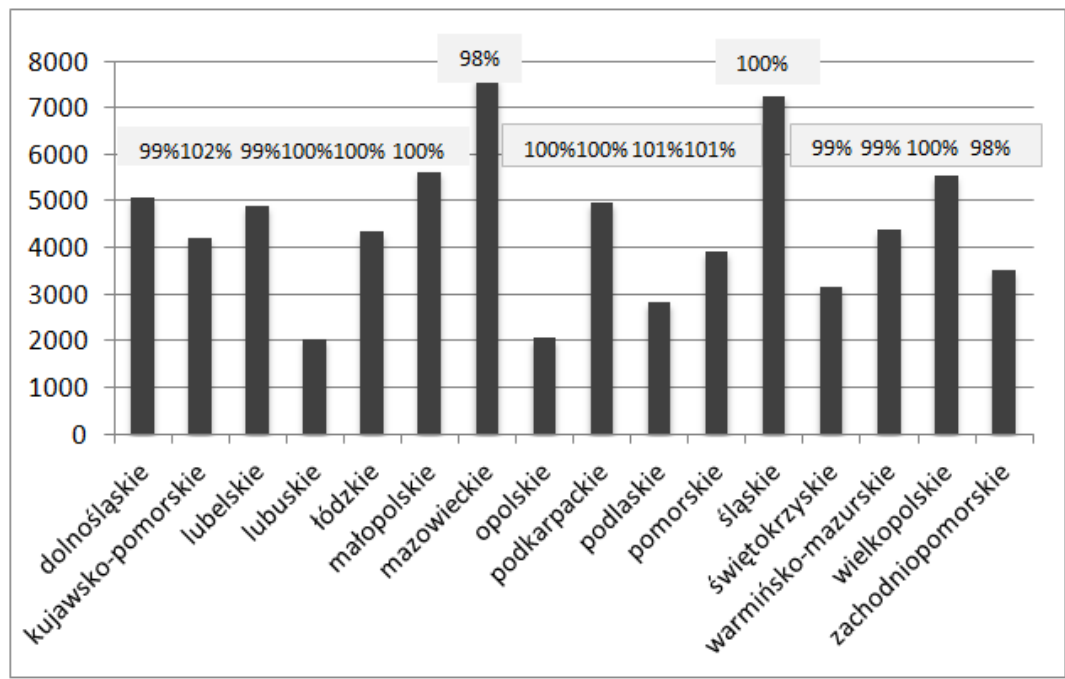

Source: Monitor Regionalny, The report-situation at the end of July 2015. Together 16 RPO programmes: the value of the contracts (EU funds) - 71.3 billion zt, contracting $-99.6 \%$

${ }^{15} \mathrm{~W}$. Lichota, Op. cit.

${ }^{16}$ Ibidem. 
Thus, $99.6 \%$ of EU funds available under the regional programmes were allocated. The expenditure declared by the beneficiaries in the applications for payment exceeded 99.1 billion zł, including EU funding - approx. 63.8 billion zł, which represents $89.1 \%$ of the allocation of the funds for 16 regional operational programmes (see chart 3$)^{17}$.

Chart 3.

\section{Spending in each ROP programme - the value of the applications for payment (EU funds, million zl) and the use of the allocation (\%).}

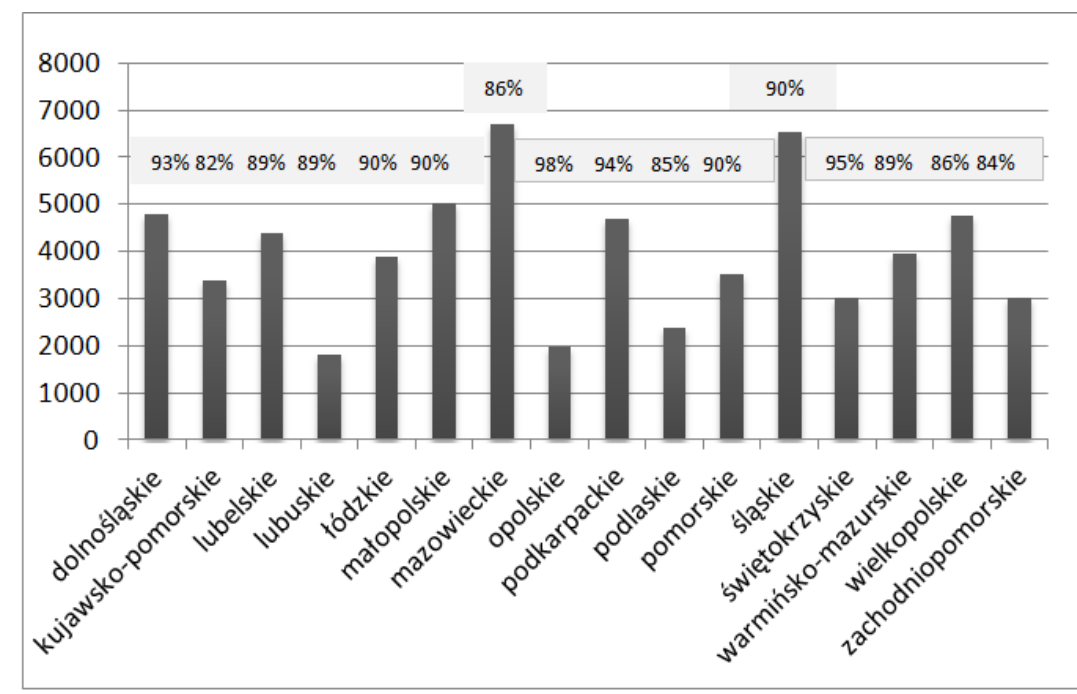

Source: Monitor Regionalny, The report - situation at the end of July 2015.

Together 16 RPO programmes: the value of the applications for payment (EU funds) -63.8 billion zl, spending $-89 \%$.

According to the data presented in chart 2, the Podkarpackie Province makes a very good use of the allocation of the funds allocated to the Regional Operational Programme for the Podkarpackie Province for the years 2007-2013. By the end of July 2015, within the mentioned Programme 4936 contracts for project financing were signed and thus the entire allocation of the funds was used. Due to the fact that several dozens of projects are still being implemented in which the final payment has not yet been paid, as a consequence of the resulting post-tender savings, the savings resulting from the final settlement of the investments, and accrued financial corrections, some additional funds can be released which ultimately can fund the Programme budget and be allocated for financing new projects.

It should also be noted that in terms of the level of payments settlement (94\%) - chart 3, the Podkarpackie Province was ranked third in the country.

Conclusions. The implementation of the Regional Operational Programme for the Podkarpackie Province for the years 2007-2013 is coming to the end. All projects under axes II-VII were contracted, the funds are being settled, and the proper implementation of projects is being verified. Most of the assumed indicators of the material implementation were achieved, though there are such indicators that will not be achieved fully or even at all. This is because of the fact that no projects were submitted or too few projects were submitted through which it would be possible to achieve the target values. Moreover, some indicators assumed to be implemented were overestimated at the stage of the program documents creation.

It should be noted that the Podkarpackie Province made a very good use of the ROP programme funds. Given the amount of the funds paid and settled in relation to the limit of available funds within the whole ROP programme, i.e. 94\%, the Podkarpackie Province ranks as the third on the background of the whole country ${ }^{18}$.

\footnotetext{
${ }^{17}$ Monitor Regionalny, The report - situation at the end of July 2015.

${ }^{18}$ Ibidem.
} 
The effects of the material implementation of the projects in the form of renovated roads, the modernization of public transport, airport infrastructure, educational, social assistance, sports, and recreation facilities, cultural institutions, or the construction of environmental infrastructure are evident in almost every municipality of the Podkarpackie Province.

\section{References}

1. A detailed description of the priorities of the Regional Operational Programme for the Podkarpackie Province for the years 2007-2013 of 15 April 2014.

2. Annex to Resolution No. 328/7836/14 of the Board of the Podkarpackie Province in Rzeszów of 11 March 2014.

3. Annual Report on the implementation of the Regional Operational Programme for the Podkarpackie Province for 2007-2013 for the year 2014.

4. Karpińska-Mizielińska W., Smuga T. (red.), Wpływ interwencji z funduszy unijnych na funkcjonowanie przedsiębiorstw i ich konkurencyjność, CeDeWu, Warszawa 2015.

5. Kornberger-Sokołowska E. (red.), Jednostki samorządu terytorialnego jako beneficjenci środków europejskich, Wolters Kluwer Polska, Warszawa 2012.

6. Lichota W., Wykorzystanie funduszy UE w ramach perspektywy 2007-2013 a możliwości pozyskania środków $\mathrm{W}$ ramach perspektywy 2014-2020 na przykładzie wybranej gminy z województwa podkarpackiego, Nierówności Społeczne a Wzrost Gospodarczy, nr 49 (1/2017).

7. Manual of expenditure eligibility under the Regional Operational Programme for the Podkarpackie Province for the years 2007-2013, September 2014.

8. Monitor Regionalny, The report - situation at the end of July 2015.

9. Periodical Report on the implementation of the Regional Operational Programme for the Podkarpackie Province for 2007-2013 for the second half of 2015.

10. Sierak J., Karasek A., Korniienko O., Godlewska A., Łubian A., Sienicki M., Boczkowska A., Kucyk A., Efekty wykorzystania dotacji unijnych w ramach Regionalnych Programów Operacyjnych w latach 2007-2013, Cz. 2, Województwa Polski Wschodniej i Centralnej, Oficyna Wydawnicza Uczelni Łazarskiego, Warszawa 2016.

11. The Regional Operational Programme for the Podkarpackie Province for the years 2007-2013 adopted by the Board of Podkarpackie Province on 10 January 2012.

12. The use of EU funds under the National Cohesion Strategy 2000-2013, Warsaw, July 2015. 